\title{
Analysis of Determinants of Stunting Incidence in 2-Year-Old Toddlers in Mamuju Regency
}

\author{
Nur Fadhila Hajar Puteri ${ }^{1}$, Ida Leida Maria ${ }^{1}$, Healthy Hidayanty ${ }^{2}$
}

Email: rafliaidillah@gmail.com

${ }^{1}$ Health Epidemiology Section, Faculty of Public Health, Hasanuddin University, Indonesia

${ }^{2}$ Department of Public Health Nutrition, Faculty of Public Health, Hasanuddin University, Indonesia

Received: July 15, 2021

Received in Revised: August 12, 2021

Accepted: August 26, 2021

\begin{abstract}
Nutritional issues like as stunting are a major source of worry in Indonesia, as is malnutrition in general. West Sulawesi is the second most affected area in Indonesia in terms of stunting incidence. The purpose of this research is to examine the relationship between low birth weight (LBW), exclusive breastfeeding, age of supplementary feeding, and Early Breastfeeding Initiation status on the prevalence of stunting in children under two in Mamuju Regency. The research method used is an analytic observational study with a retrospective cohort design. This research will be carried out in two Puskesmas with the highest number of stunting cases in Mamuju Regency, namely Bambu Health Center and Keang Health Center. The population in this study was 928 baduta. The study sample was drawn using the proportion calculation method so that the research sample was divided into 65 exposed groups and 65 non-exposed groups so that the total sample was 130 children under five. The results showed that there was a relationship between the incidence of LBW (0.00), breastfeeding (0.00), age of giving complementary feeding (0.00), early breastfeeding initiation status $(0.00)$ with stunting incidence in children under two in the district. Mamuju. Non-exclusive breastfeeding is 36 times more risky for stunting in children under two in Mamuju Regency. In order to reduce the incidence of stunting, it is necessary to increase promotive efforts to motivate mothers to give exclusive breastfeeding to their babies.
\end{abstract}

Keywords: Low Birth Weight, Early Initiation of Breastfeeding, Exclusive Breastfeeding, Complementary Feeding, Stunting

\section{Introduction}

Stunting is one of the most serious nutritional problems in Indonesia. Stunting is a significant issue because it shapes the next generation. Stunting is a condition in which a person's height is determined by their age. It is known that chronic nutritional problems may have occurred as a result of stunting. The issue of short toddlers demonstrates the existence of chronic nutritional problems that are influenced by the mother's/prospective mother's health, the fetal period, and infancy/toddlerhood, including diseases encountered during infancy and other issues that have an indirect effect on health (Kemenkes, 2018).

The problem of short toddlers is a worldwide problem. According to WHO data, $55 \%$ of children under five who experience stunting are Asian toddlers, while more than a third are from Africa. The prevalence of stunting in Indonesia's Under Five Years Old Infants (Toddler) in 2015 was $36.4 \%$. This means that more than a third or about 8.8 million children under five have nutritional problems where their height is below the standard for their age (WHO, 2019). 
Riskesdas data shows a decrease in the number of stunting cases in Indonesia from $37.2 \%$ in 2013 to $30.8 \%$ in 2018 (Kemenkes, 2018).

West Sulawesi is the second highest region for stunting cases. Although the number of cases has decreased, West Sulawesi is still ranked second for stunting toddlers (Kemenkes, 2018). It is possible that the high incidence of stunting is due to the high rate of low birth weight. LBW instances were reported in Mamuju in 2017, according to data from the West Sulawesi Provincial Health Office. There were 128 occurrences of Low Birth Weight (LBW) in Mamuju in 2017. (Kemenkes, 2018).

Mamuju District Health Office reported that the prevalence of stunting in the district was 39.6 percent based on the findings of the 2017 Nutrition Status Monitoring conducted by the district health office. Among the Puskesmas operating areas in Mamuju Regency, the highest incidence of stunting (0-59 months) is found at Keang Health Center, where it accounts for 27.16 percent of the total, Tapalang Health Center accounts for 13 percent, and Bambu Health Center accounts for 12 percent (Kemenkes, 2018). According to study performed by (Barir et al., 2019), the incidence of stunting is closely linked to the length of the baby's delivery, the weight of the baby's birth, the duration of exclusive breastfeeding, and the timing of supplementary feeding. The wealth of the family, the age of the mother, her attitude, the height of the mother, her profession, her education, and her knowledge all have an indirect impact.

According to studies conducted in Nepal, infants born with a low birth weight are more likely to be stunted as they grow older (Ni'mah et al., 2015). In line with the findings of a study performed in Makelle City, Ethiopia, by Id et al. (2019), who discovered that low birth weight was a factor linked with the frequency of stunting in children. Stunting is affected by children's exclusive breastfeeding, which occurs in conjunction with low birth weight (LBW) (Aridiyah et al., 2015a). In Surabaya, research has shown that babies who do not get exclusive breastfeeding are at a higher risk of stunting (Ni'mah et al, 2015), and that this risk increases with age.

Furthermore, the initiation of breastfeeding at a young age is another factor that influences the incidence of stunting (Yuliawati et al., 2019). The practice of giving babies with early start of breastfeeding (IMD) chances will decrease the prevalence of infectious illnesses and increase the likelihood of exclusive breastfeeding being effective in the future (Sumiaty, 2017). According to a study performed in Boyolali, children who did not get early start of breastfeeding (IMD) had a 2.63 (1.02-6.82) times greater risk of suffering stunting than other children (Permadi et al., 2016). Due to the above context, researchers at Mamuju Regency are interested in learning more about the factors that contribute to stunting in 2-year-old children.

\section{Methods}

\section{Research Design and Location}

The type of research used is an analytic observational study with a retrospective cohort design. A retrospective cohort study was conducted by comparing groups of individuals who were similar in many respects but differed in certain characteristics (occurrence of LBW, Exclusive Breastfeeding, Age of Complementary Breastfeeding, Early Breastfeeding Initiation Status) and in certain outcomes (stunting and not stunting). The retrospective cohort looked at the risk factors and effects that had occurred in the past prior to the start of the study. Thus the variable is measured through historical records. This research will be carried out in two Puskesmas with the highest number of stunting cases in Mamuju Regency, namely Bambu Health Center and Keang Health Center. The research was carried out after obtaining permission from the Hasanuddin University code of ethics research with protocol number 20620052141, Mamuju 
District Health Office, Bambu Health Center and Keang Health Center, and asking for approval from respondents who were selected as samples.

\section{Population and Sample}

The children in this research were all under the age of five who lived in the working area of the Bambu Health Center, and the Keang Health Center had as many as 928 toddlers in its care at one time. The sample used in this research consisted of 130 participants, each of whom was divided into two groups of 65 exposed participants and 65 unexposed participants.

\section{Data Collection}

Data collection is done by; (1) Collecting data on babies born in 2018 at the Bambu Health Center and Keang Health Center according to the number of samples, each of which is 65 in the exposed (stunting) group and 65 children in the unexposed (non-stunted) group; (2) Check whether the sample candidates have KMS or cohort data at the Bambu Health Center and the Keang Health Center; (3) Tracing or taking retro data whether after the baby was born, the baby was placed on the mother's chest or did IMD; (5) Tracing retro data on the implementation of exclusive breastfeeding for 6 months; (6) Tracing/retrieving retro data at what age babies started to be given complementary feeding.

\section{Data Analysis}

The data analysis method utilized in this research included univariate and bivariate analysis, as well as the Chi-Square test, among other things. We used the Statistical Package for Social Science (SPSS) to carry out our investigation (SPSS)

\section{Results and Discussion}

Table 1. Frequency Distribution Based on Characteristics of Respondents

\begin{tabular}{|c|c|c|c|c|c|c|}
\hline \multirow{2}{*}{$\begin{array}{l}\text { Characteristics of } \\
\text { Respondents }\end{array}$} & \multicolumn{2}{|c|}{ Stunting } & \multicolumn{2}{|c|}{ Not Stunting } & \multicolumn{2}{|c|}{ Sum } \\
\hline & n (65) & $\%$ & n (65) & $\%$ & n (130) & $\%$ \\
\hline \multicolumn{7}{|l|}{ Age } \\
\hline $20-35$ th & 45 & 69,2 & 57 & 55,9 & 102 & 78,5 \\
\hline$>35$ th & 20 & 15,4 & 8 & 6,2 & 28 & 21,5 \\
\hline \multicolumn{7}{|l|}{ The Last Education } \\
\hline $\begin{array}{l}\text { Graduated from Elementary } \\
\text { School }\end{array}$ & 25 & 38,5 & 3 & 4,6 & 28 & 21,5 \\
\hline Graduated from Junior School & 15 & 23,1 & 16 & 24,6 & 31 & 23,8 \\
\hline Graduated from High School & 24 & 36,9 & 41 & 63,1 & 65 & 50,0 \\
\hline Higher Education & 1 & 1,5 & 5 & 7,7 & 6 & 4,6 \\
\hline
\end{tabular}

In the first table, it can be seen that the respondents in the age range 20-35 years were divided into two groups: those who were stunted (69.2 percent) and those who were not stunted (57.9 percent). In contrast, the most recent education received by respondents was elementary school graduation, with 25 individuals (38.5 percent) in the stunted group and 41 (63.1 percent) high school graduates in the non-stunted group having completed their studies in the last year.

Table 2. Determinants of Stunting Incidence in Baduta in Mamuju Regency in 2020

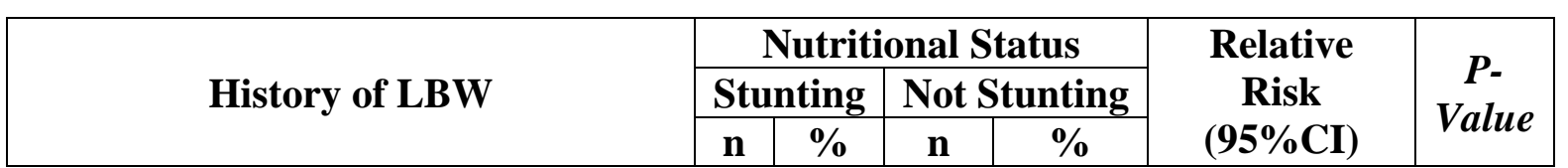




\begin{tabular}{|c|c|c|c|c|c|c|}
\hline High Risk & 56 & 86,2 & 40 & 61,5 & \multirow{2}{*}{$\begin{array}{c}3,889(1,640- \\
9,220)\end{array}$} & \multirow[t]{2}{*}{0,003} \\
\hline Low Risk & 9 & 13,8 & 25 & 38,5 & & \\
\hline \multirow[t]{3}{*}{ Exclusive Breast Milk } & \multicolumn{4}{|c|}{ Nutritional Status } & \multirow{3}{*}{$\begin{array}{c}\text { Relative } \\
\text { Risk } \\
(95 \% \mathrm{CI}) \\
\end{array}$} & \multirow{3}{*}{$\begin{array}{c}P- \\
\text { Value }\end{array}$} \\
\hline & \multicolumn{2}{|c|}{ Stunting } & \multicolumn{2}{|c|}{ Not Stunting } & & \\
\hline & $\mathbf{n}$ & $\%$ & $\mathbf{n}$ & $\%$ & & \\
\hline High Risk & 49 & 75,4 & 5 & 7,7 & 36,750 & 0,000 \\
\hline Low Risk & 16 & 24,6 & 60 & 92,3 & $\begin{array}{l}(12,5 / 1- \\
107,436)\end{array}$ & \\
\hline \multirow[t]{3}{*}{ Mp-BREAST MILK } & \multicolumn{4}{|c|}{ Nutritional Status } & \multirow{3}{*}{$\begin{array}{c}\text { Relative } \\
\text { Risk } \\
(95 \% \mathrm{CI})\end{array}$} & \multirow{3}{*}{$\begin{array}{c}P- \\
\text { Value }\end{array}$} \\
\hline & \multicolumn{2}{|c|}{ Stunting } & \multicolumn{2}{|c|}{ Not Stunting } & & \\
\hline & $\mathbf{n}$ & $\%$ & $\mathbf{n}$ & $\%$ & & \\
\hline High Risk & 49 & 75,4 & 5 & 7,7 & \multirow{2}{*}{$\begin{array}{c}36,750 \\
(12,571- \\
107,436)\end{array}$} & \multirow[t]{2}{*}{0,000} \\
\hline Low Risk & 16 & 24,6 & 60 & 92,3 & & \\
\hline \multirow[t]{3}{*}{ Early Breastfeeding Initiation (IMD) } & \multicolumn{4}{|c|}{ Nutritional Status } & \multirow{3}{*}{$\begin{array}{c}\text { Relative } \\
\text { Risk } \\
(95 \% \mathrm{CI})\end{array}$} & \multirow{3}{*}{$\begin{array}{c}P- \\
\text { Value }\end{array}$} \\
\hline & \multicolumn{2}{|c|}{ Stunting } & \multicolumn{2}{|c|}{ Not Stunting } & & \\
\hline & $\mathrm{n}$ & $\%$ & $\mathrm{n}$ & $\%$ & & \\
\hline High Risk & 22 & 33,8 & 11 & 16,9 & \multirow{2}{*}{$\begin{array}{c}2,5129 \\
(1,098-5,744)\end{array}$} & \multirow[t]{2}{*}{0,000} \\
\hline Low Risk & 43 & 66,2 & 54 & 83,1 & & \\
\hline
\end{tabular}

When the test was completed, the probability value ( $\mathrm{p}$-value) was 0.0030 .05 (showing a statistically significant connection between the occurrence of low birth weight (LBW) and stunting in babies), according to the findings of the study. A baby weighing 2500 grams has a chance of 3,889, with a relative risk of 1,640-9,220 for every 1,000 grams that the infant weighs. (95 percent confidence interval). The findings of the test for exclusive breastfeeding resulted in a probability value (p-value) of 0.0000 .05 (), suggesting that there is a statistically significant connection between exclusive breastfeeding and stunting in children under the age of five (see Figure 1). Infants who do not get exclusive breastfeeding have a 36,750 percent chance of not obtaining it, with a relative risk ranging from 12,571 to 107,436 percent. (95 percent confidence interval). The findings of the Age of Complementary Feeding Test produced a probability value (p-value) of 0.0000 .05 (), suggesting that there is a statistically significant connection between the Age of Complementary Breastfeeding and stunting in children under the age of five in this population. The chance of a newborn getting MP-ASI not being the appropriate age is 36,750 months, with a relative risk increasing from 12,571 to 107,436 months for each month the probability is exceeded. (95 percent confidence interval). A 0.0000 .05 probability value (p-value) was obtained from the Early Breastfeeding Initiation Status test, which indicated a statistically significant connection between Early Breastfeeding Initiation Status (IMD) and stunting in children under the age of two. Infants who are not permitted to breastfeed are 2.512 times more likely to die than those who are. The relative risk ranges from 1.098 to 5.744. (95 percent confidence interval). The most significant predictors of stunting in children under the age of two in Mamuju Regency are exclusive breastfeeding and the age at which supplementary feeding is introduced into the household (MP-ASI). 
Table 3. Multivariate Analysis of Determinants of Stunting Incidence in Baduta in Mamuju Regency in 2020

\begin{tabular}{|c|c|c|c|c|c|c|c|c|}
\hline \multirow{2}{*}{\multicolumn{2}{|c|}{ Research Variable }} & \multirow[t]{2}{*}{ B } & \multirow[t]{2}{*}{ S.E } & \multirow{2}{*}{ Wald } & \multirow{2}{*}{ Sig. } & \multirow[t]{2}{*}{ OR } & \multicolumn{2}{|c|}{$\begin{array}{c}95 \% \text { C.I } \\
\text { for } \operatorname{Exp}(\mathbf{B})\end{array}$} \\
\hline & & & & & & & Lower & Upper \\
\hline \multirow{4}{*}{$\begin{array}{l}\text { Step } \\
1^{\mathrm{a}}\end{array}$} & LBW incident & 1.327 & .650 & 4.164 & .041 & 3.768 & 1.054 & 13.476 \\
\hline & $\begin{array}{l}\text { Exclusive } \\
\text { Breastfeeding }\end{array}$ & 4.017 & .628 & 40.912 & .000 & 55.536 & 16.218 & 190.174 \\
\hline & IMD Status & 1.738 & .593 & 8.594 & .003 & 5.688 & 1.779 & 18.183 \\
\hline & Constant & -11.196 & 1.963 & 32.534 & .000 & .000 & & \\
\hline
\end{tabular}

A multivariate analysis was carried out utilizing multiple logistic regression using a backward stepwise (conditional) approach, and the findings are shown below. Exclusive breastfeeding, with an odds ratio of 55,536 and a p value of 0.000 , is the variable that has the greatest impact on the incidence of stunting.

The importance of exclusive breastfeeding for infants aged 0-6 months is very important, because at this age the enzymes in the intestines cannot digest food other than breast milk, in addition to removing the rest of the absorption of food also cannot be done because the kidneys are not perfect. Exclusive breastfeeding itself has many benefits, besides increasing immunity, it can also increase the bond between mother and baby, as well as fulfill nutritional needs, cheaply and hygienically. Breastfeeding that is not as recommended, namely exclusive breastfeeding for the first 6 months can cause the baby to suffer from malnutrition and malnutrition. Malnutrition in infants can cause clinically impaired growth, psychomotor, cognitive and social disorders. Another impact, namely the health and nutrition status of Indonesian children, is still a concern (Annisa et al., 2019).

Infant growth and development requires a balanced and relatively large nutritional intake, but the baby's ability to eat is limited by the digestive tract which is still in the maturation stage. The only food that is suitable and can meet the nutritional needs of infants in the first 6 months is breast milk (Paudel et al., 2012). Children who do not get exclusive breastfeeding during the first six months of life are at a higher risk of malnutrition later in life. Because to development problems, children's growth may be significantly limited. This research supports the findings of Ni'mah et al(2015) that there is a connection between exclusive breastfeeding and stunting incidence, with an odds ratio of 4,643 for the latter. These results, on the other hand, are in opposition to Yuliawati's (2019) study, which showed that there was no statistically significant connection between exclusive breastfeeding and the prevalence of stunting in babies in Majene.

Additionally, in addition to the impact of exclusive breastfeeding on the prevalence of stunting, there is a negative relationship between stunting and the availability of supplementary feeding. Breast milk substitutes are often provided to babies over 6 months of age. Complementary feeding is intended to fulfill the nutritional requirements of infants that cannot be supplied by breast milk, as well as to build the immune system and development of the baby's immune system via food and drink. (Dewi and colleagues, 2020). However, if Guide to Breastfeeding Complementary Feeding (MP-ASI) is given too early, it can increase infant mortality, interfere with the digestive system and cause babies to have less appetite for breastfeeding. However, if MP-ASI is given too late, the baby becomes difficult to receive complementary foods. At the age of 6 months, babies already have a chewing reflex with stronger digestion so they can receive complementary foods (Aridiyah et al., 2015b). 
This study is consistent with the findings of Rahuni et al. (2019), who discovered a connection between the pattern of supplementary feeding and the prevalence of stunting in young children. The frequency with which MP-ASI is administered has an effect on the prevalence of stunting in toddlers. MP-ASI is beneficial in addressing the nutritional deficiency that occurs in breast milk. When the infant reaches this stage, he or she starts to be exposed to meals that have a somewhat thick texture. This is done in order for babies to begin exercising their oral motor skills.

The behavior of Early Breastfeeding Initiation has a role in the occurrence of stunting as well as other factors (IMD). One of the advantages of IMD for moms is that it has been shown to enhance breast milk supply in certain cases. The baby's sucking reflex on the mother's nipple will stimulate milk production. The earlier and more often the baby suckles, the breasts will produce more milk (Annisa et al, 2019). Babies who get IMD have more advantages than babies who don't because they get important elements from colostrum and reduce the risk of stunting. The nutrients in colostrum help the digestive system so that it facilitates the absorption of minerals in the body (Annisa et al, 2019).

Success in getting the nipple allows the baby to get colostrum. Nutrients in colostrum are needed by babies in the early days of life, including for growth in height. This is because colostrum contains immunoglobulin A protein which can provide protection for babies up to 6 months of age. In addition, there are minerals needed by newborns, such as calcium, potassium and sodium which play a role in bone formation (Murti, 2017).

Toddlers with a history of low birth weight are also more susceptible to various infectious diseases, such as diarrhea and lower respiratory tract infections. They also have a higher risk of developing complications like anemia, chronic lung diseases, fatigue, and loss of appetite when compared to other children. -children who are born at a healthy weight (Berhe et al., 2019). Infants born at low birth weight (LBW) grow and develop at a slower pace than babies born at a normal birth weight. In the womb, babies with long-term growth retardation (LBW) suffer development delays that may continue until they are born, resulting in an inability to grow and develop properly for their age at birth (Fitri, 2018).

LBW infants will grow and develop at a slower rate than their normal-weight counterparts. Baby's with low birth weight (LBW) suffer from intrauterine growth retardation, which will last until the following age after delivery, resulting in slower growth and development than normal-weight infants, as well as a greater likelihood of failing. strictly sticking to the growth rate that is expected to be attained at postnatal age (Supriyanto et al., 2018). Babies with low birth weight also experience digestive disorders because the digestive tract is not functioning properly such as absorbing fat and digesting protein less than optimally, resulting in a lack of nutrient reserves in the body. As a result, the growth of babies with LBW will be disrupted. If this situation continues with inadequate feeding, frequent infections and inadequate health care, it will lead to stunting (Fitri, 2018).

So from the four determinant factors above, it is appropriate for us to know the causes and how to overcome them because stunting can be prevented through prevention efforts through breastfeeding for toddlers 0-2 years, providing complementary feeding for infants 6 months and older, early initiation of breastfeeding behavior, and strive to improve nutrition so as not to give birth to LBW children.

\section{Conclusion}

A relationship exists between low birth weight (LBW), early breastfeeding initiation status, exclusive breastfeeding, and the age of complementary breastfeeding in Mamuju Regency, but 
the relationship is strongest for children under the age of two. Exclusive breastfeeding and the age of complementary breastfeeding have the greatest risk influence on stunting in Mamuju Regency children under the age of two. Through regular counseling during and after pregnancy, it is recommended that health-care workers continue to increase promotional efforts to encourage mothers to be able to provide exclusive breastfeeding to their infants, as well as to educate prospective mothers about the nutritional requirements of infants in accordance with the complementary feeding principle.

\section{References}

Annisa, N., Sumiaty, S.Tondong, H.I. (2019). Hubungan Inisiasi Menyusu Dini dan ASI Eksklusif dengan Stunting pada Baduta Usia 7-24 Bulan. Jurnal Bidan Cerdas, $1:(3) 137-143$

Aridiyah, F.O., Rohmawati, N.Ririanty, M. (2015a). Faktor-faktor yang Mempengaruhi Kejadian Stunting pada Anak Balita di Wilayah Pedesaan dan Perkotaan (The Factors Affecting Stunting on Toddlers in Rural and Urban Areas). e-Jurnal Pustaka Kesehatan, 3:(1)163-170

Aridiyah, F.O., Rohmawati, N.Ririanty, M. (2015b). Faktor-faktor yang Mempengaruhi Kejadian Stunting pada Anak Balita di Wilayah Pedesaan dan Perkotaan (The Factors Affecting Stunting on Toddlers in Rural and Urban Areas). Pustaka Kesehatan, 3:(1)163-170

Barir, B., Murti, B.Pamungkasari, E.P. (2019). The Associations between Exclusive Breastfeeding, Complementary Feeding, and the Risk of Stunting in Children Under Five Years of Age: A Path Analysis Evidence from Jombang East Java. Journal of Maternal and Child Health, 4:(6)486-498

Berhe, K., Seid, O., Gebremariam, Y., Berhe, A.Etsay, N. (2019). Risk factors of stunting (chronic undernutrition) of children aged 6 to 24 months in Mekelle City, Tigray Region, North Ethiopia: An unmatched case-control study. Plos one, 14:(6)e0217736

Dewi, S.Mu'minah, I. (2020). Pemberian Mp-Asi Tidak Berhubungan Dengan Kejadian Stunting Pada Anak Usia 1-3 Tahun Di Wilayah Kerja Puskesmas Sumbang I Kabupaten Banyumas. INFOKES Journal, 10:(1)5-10

Fitri, L. (2018). Hubungan BBLR Dan Asi Ekslusif Dengan Kejadian Stunting Di Puskesmas Lima Puluh Pekanbaru. Jurnal Endurance: Kajian Ilmiah Problema Kesehatan, 3:(1)131-137

Kemenkes, R. (2018). Laporan Nasional Riskesdas 2018. Jakarta: Kemenkes RI, 154-66

Murti, N.N. (2017). Hubungan Inisiasi Menyusui Dini (Imd) Dengan Laktasi Pada Ibu Post Partum Normal Di Rumah Sakit Khusus Bersalin Balikpapan Tahun 2016. MMJ (Mahakam Midwifery Journal), 2:(1)33-45

Ni'mah, K.Nadhiroh, S.R. (2015). Faktor yang Berhubungan dengan Kejadian Stunting pada Balita. Media Gizi Indonesia, 10:(1)13-19

Ni'mah, K.Nadhiroh, S.R. (2015). Faktor yang berhubungan dengan kejadian stunting pada balita. Media Gizi Indonesia, 10:(1)13-19

Paudel, R., Pradhan, B., Wagle, R., Pahari, D.Onta, S. (2012). Risk factors for stunting among children: a community based case control study in Nepal. Kathmandu University Medical Journal, 10:(3)18-24 
Permadi, M.R., Hanin, D., KusnandarIndarto, D. (2016). Risiko Inisiasi Menyusui Dini dan Praktek ASI Eksklusif Terhadap Kejadian Stunting pada Anak 6-24 Bulan. Penelitian Gizi dan Makanan, 39:(1)9-14

Rahyuni, M.Rosyada, A. 2019. Pengaruh Pemberian Mpasi Dini Dengan Kejadian Stunting Pada Balita 24-59 Bulan Di Indonesia (Analisis Data Ifls 5). Sriwijaya University.

Sumiaty, S. (2017). Pengaruh Faktor Ibu dan Pola Menyusui terhadap Stunting Baduta 6-23 Bulan. Jurnal Ilmiah Bidan, 2(2), 1-8.

Supriyanto, Y., Paramashanti, B.A.Astiti, D. (2018). Berat badan lahir rendah berhubungan dengan kejadian stunting pada anak usia 6-23 bulan. Jurnal Gizi dan Dietetik Indonesia (Indonesian Journal of Nutrition and Dietetics), 5:(1)23-30

WHO 2019. World health statistics 2019: monitoring health for the SDGs, sustainable development goals, World Health Organization.

Yuliawati, e. (2019). Inisisasi Menyusu Dini, Keanekaragaman Makanan Dan Jaminan Kesehatan Terhadap Kejadi Stunting Pada Anak Usia 24-59 Bulan Di Kabupaten Kepulauan Mentawai Sumatera Barat Tahun 2019. Human Care Journal, 04(03):(7

Yuliawati, E., Sulung, N.Hasnita, E. (2019). Inisiasi Menyusui Dini, Keanekaragaman Makanan dan Jaminan Kesehatan Terhadap Kejadian Stunting. Jurnal Human Care, 4:(3)132-13 